\title{
Pengaruh Intensitas Penggunaan Smartphone terhadap Kejadian Myopia Pada Remaja di Tengah Pandemi Covid-19 JABODETABEK
}

\author{
Atti Kartikawati ${ }^{1 *}$, Erni Suprihatin ${ }^{2}$ dan Anung Inggito Maksus ${ }^{3}$ \\ Akademi Refraksi Optisi (ARO) Kartika Indera Persada, Gedung Indra Sentra Unit ap/ao Jl. Letjend \\ Suprapto no. 60 Cempaka Putih Jakarta Pusat 10520
}

Correspondence: lpm.arokartika@gmail.com

Received: 30 Juni 2021 - Revised: 01 Agustus 2021 - Accepted: 16 Agustus 2021

\begin{abstract}
Abstrak. Di era pandemic Covid-19 saat ini peran smartphone menjadi penunjang satu-satunya sarana dalam pembelajaran daring, selain laptop. Dari segi intensitas penggunaan smartphone atau handphone bisa menjadikan sebab yang berdampak pada Kesehatan mata, dalam pembahasan ini adalah myopia. Sejalan dengan tujuan diadakan penelitian ini adalah untuk mengetahui seberapa besar pengaruh dari intensitas penggunaan smartphone terhadap myopia. Melalui progam pengabdian Masyarakat yang dilakukan secara mandiri oleh mahasiswa, dalam pengawasan dosen pembimbing. Pada domisili tempat tinggalnya. Yaitu sekitar JABODETABEK. Intensitas penggunaan smartphone atau handphone mempengaruhi terhadap kelainan refraksi pada khususnya myopia, hal dibuktikan dengan uji regresi logistic Dengan SPSS 26 yaitu $0,000<0,05$ dengan besarnya pengaruhnya yaitu $25,5 \%$ dari intensitas penggunaan handphone dan $74,5 \%$ dipengaruhi oleh variabel lain. Pengunaan uji regresi logistic untuk penelitian ini sudah tepat, hal ini dibuktikan dengan Hosmer and Lemeshow Test $>0,05$ yaitu $(0,06>0,05)$ maka Ho diterima. Hal ini diartikan bahwa model yang pakai sesuai dengan pengamatan. Begitupun dengan ketepatan dalam memprediksi pengujian ini sebesar $72,8 \%$.
\end{abstract}

Kata kunci: smartphone, myopia , Remaja

Citation Format: Kartikawati, A., Suprihatin, E. \& Maksus, A.I.. (2021). Pengaruh Intensitas Penggunaan Smartphone terhadap kejadian Myopia Pada Remaja di tengah Pandemi Covid-19 JABODETABEK. Prosiding Seminar Nasional Abdimas Ma Chung (SENAM), 32-39. 


\section{PENDAHULUAN}

Tidak dapat dipungkiri pada era pandemic Covid-19 mampu mengubah kebiasaan masyarakat pada umumnya, baik dari segi perekonomiannya juga dari segi Pendidikan. Karena tidak adanya pembelajaran secara langsung, otomatis pembelajaran dilaksanakan secara daring. Dalam hal ini siswa menggunakan gadget untuk pembelajaran jarak jauh. Lamanya penggunaan gadget dan smartphone sangat bisa mempengaruhi kesehatan mata. Dalam penelitian ini lebih berfokus pada remaja. Menurut WHO (2018), remaja adalah penduduk dalam rentang usia 10-19 tahun, menurut Peraturan Menteri Kesehatan RI Nomor 25 tahun 2014, remaja adalah penduduk dalam rentang usia 10-18 tahun. Untuk penelitian ini berfokus pada remaja usia 10-19 tahun.

Pada usia remaja yang menggunakan smartphone tidak hanya untuk kebutuhan pembelajaran tetapi juga untuk berselancar didunia maya. Bahkan tidak sedikit remaja yang menggunakan smartphone untuk bermain game, tanpa pernah berpikir dampak yang ditimbulkan untuk kesehatan mata. Dalam penelitian ini berfokus pada myopia. Menurut (Bremond-Gignac, 2020) miopia merupakan aomali refrakta, masalah kesehatan masyarakat global, ditinjau dari sudut pandang peningkatan panjang aksial bola mata. Begitu pula menurut (Wolffsohn et al., 2019) menyatakan bahwa miopia merupakan kesalahan dari sinar sejajar sumbu optik masuk ke mata, jatuh di depan fokus retina ketika akomodasi okuler dalam keadaan santai, akibat sumbu bola mata yang panjang yang diakibatkan kornea mata terlalu melengkung, daya optik lensa yang meningkat atau disebabkan oleh kornea mata yang terlalu melengkung dan daya optik yang meningkat. Myopia merupakan kelainan refraksi dimana sinar cahaya paralel yang memasuki mata di fokus di depan retina, Myopia, disebut juga dengan istilah rabun jauh/terang dekat (shortsightedness), salah satu dari lima besar penyebab kebutaan di seluruh dunia, sehingga dapat dikatakan bahwa myopia kelainan refraksi yang relatif banyak menyebabkan gangguan penglihatan, (Sativa, 2010)

Rabun jauh atau myopia yang terjadi dapat diketahui melalui pemeriksaan mata subjektif dan apakah intensitas penggunaan smartphone mempengaruhinya? Ini yang akan dikaji lebih mendalam melalui penelitian ini. Intensitas Penggunaan smartphone menurut (Falaki et al., 2010) dalam penelitiannya menunjukkan bahwa meskipun ada perbedaan antara kuantitatif kualitatif pengguna Ponsel Cerdas atau Smartphone, walau dengan kesamaan tugas. Yaitu dengan mempelajari perilaku pengguna untuk beberapa aspek 
utama dari penggunaan Ponsel Cerdas atau Smartphone model yang sama dapat menggambarkan semua pengguna, meski setiap pengguna memiliki parameter model yang berbeda misalnya waktu interaksinya. Dari penelitian yang diadakan sebelumnya oleh (McCrann et al., 2021) dengan Regresi logistik multinomial mengungkapkan bahwa kelainan refraksi rabun secara statistik secara signifikan terkait dengan peningkatan penggunaan data smartphone harian (rasio odds 1,08, 95\% CI 1,03-1,14) serta peningkatan usia (rasio odds 1,09, 95\% CI 1,02-1,17) dan jumlah orang tua rabun (rasio odds 1,55, 95\% CI 1,06-2,3). Tujuh puluh tiga persen siswa percaya bahwa teknologi digital dapat berdampak buruk pada mata mereka.

Dari latar belakang tersebut, dalam Program Pengabdian Masyarakat Akademi Refraksi Optisi Kartika Indera Persada ini mengadakan penelitian dengan pemeriksaan di tengah Pandemi Covid-19, dilaksanakan pada 2 (dua) bulan Januari-Februari 2021. Memeriksa remaja usia 10-19 tahun yang masih berstatus pelajar. Dan untuk menghindari kerumunan dan memutus tali penyebaran Virus Corona, sehingga kami pihak institusi mengadakan program pengabdian masyarakat secara mandiri. Yaitu dengan memberikan instruksi kepada mahasiswa dengan pendampingan jarak jauh dari dosen pembimbing. Mahasiswa cukup memeriksa 20 orang yang terdiri dari 10 Guru dan 10 siswa, pada daerah atau wilayah terdekat dengan mahasiswa.

\section{MASALAH}

Pada era pandemic covid-19 intensitas penggunaan smartphone untuk usia remaja antara 10-19 tahun meningkat dikarenakan berbagai kebutuhan diantaranya pembelajaran daring, yang merupakan solusi pembelajaran jarak jauh untuk menghindari terpaparnya virus atau lebih tepatnya memutus rantai penyebaran virus. dalam hal ini terkadang remaja tidak memperhatikan dampaknya bagi kesehatan mata, khususnya myopia.

\section{METODE PELAKSANAAN}

Pada penelitian ini, metode yang digunakan adalah dengan kuantitatif deskriptif menurut (Lapau, 2014) membagi kuantitatif deskriptif dengan tiga bagian yaitu deskriptif studi kasus, korelasi dan cross sectional. Dalam hal ini penulis menggunakan korelasi. Dengan metode survey dengan memberikan angket dalam bentuk google formulir yang diisi pada saat proses pemeriksaan oleh mahasiswa kepada siswa, yang berdomisili terdekat dengan mahasiswa dikarenakan kondisi wabah covid-19. Yaitu wilayah Jakarta, 
Bogor, Depok, Tangerang dan Bekasi. Pemeriksaan mata dengan menggunakan snellen chart untuk skrining mata dan mengunakan trial lens untuk mengetahui myopia. Populasi siswa yang terdapat myopia 520 siswa. Untuk data yang diolah digunakan seluruh populasi, untuk mendapatkan hasil yang maksimal. Menggunakan uji Regresi Logistic non parametik untuk mengetahui apakah ada pengaruh intensitas penggunaan smartphone terhadap kejadian myopia pada usia remaja. Adapun langkah-langkah selanjutnya dalam penelitian ini, sesuai dengan penelitian (Azizah \& Chandra, 2017) sebagai berikut:

1. Menentukan model regresi logistik

2. Menguji signifikan parameter (uji parsial)

3. Menguji rasio likelihood (Hosmer \& lemeshow and, 2007)

4. Menerapkan uji kecocokan model untuk mengevaluasi cocok tidaknya model dengan data.

5. Estimasi model regresi.

\section{HASIL DAN PEMBAHASAN}

Data yang diperoleh dari kegiatan Program Pengabdian Masyarakat merupakan data primer yang didapatkan langsung pada saat pelaksanaan kegiatan tersebut penelitian dengan menggunakan kuantitatif ini, berdasarkan apa yang terjadi antar proses dalam menjalani Program Pengabdian Masyarakat. Dalam mengambil suatu permasalahan yang ada, melalui data yang diolah dengan uji regresi logistik menggunakan SPSS 26. Memperoleh hasil berupa data primer. (Haryanti, 2021).

1. Menentukan Model Regresi Logistik

Tabel 1. Model Regresi Logistik

\begin{tabular}{lllllllll}
\hline \multicolumn{7}{c}{ Variables in the Equation } \\
\hline & B & S.E. & Wald & df & Sig. & Exp(B) \\
\hline Step 1 $^{\text {a }}$ & $\begin{array}{l}\text { intensitas } \\
\text { penggunaan } \\
\text { Handphone }\end{array}$ & 1,195 & 0,223 & 28,839 & & 0,000 & 3,305 \\
& & & & & & & \\
& & & & & & & \\
Constant & $-3,142$ & 0,500 & 39,472 & 1 & 0,000 & 0,043 \\
\hline & a. Variable(s) entered on step 1 : intensitas penggunaan Handphone . &
\end{tabular}


Dari tabel 1 yaitu model Regresi Logistik dengan nilai $\operatorname{Exp(B)~3,305~}$ memberikan arti bahwa nilai tersebut merupakan nilai dari intensitas penggunaan smartphone yang memberikan pengaruh.

2. Menguji signifikan parameter (uji parsial)

Selanjutnya, dilakukan uji parsial yang digunakan untuk mengetahui apakah variabel intensitas penggunaan smartphone berpengaruh terhadap kejadian Miopia pada remaja. Terlihat pada label 1 nilai $p$-value (sig.) semua variabel kurang dari 0,05. hal ini dapat diartikan bahwa intensitas penggunaan smartphone berpengaruh dengan nilai sig. $0,000<0,05$ itu mempunyai pengaruh terhadap kejadian Miopia pada remaja, sementara nilai contans $0,000<0,05$.

3. Menguji rasio likelihood (Hosmer \& lemeshow, 2007)

Tabel 2. Hasil uji rasio likelihood

\section{Hosmer and Lemeshow Test}

\begin{tabular}{llll} 
Step & Chi-square & df & Sig. \\
\hline 1 & 3,384 & 1 & 0,066 \\
\hline
\end{tabular}

Hipotesis :

Ho : Model yang terbentuk sesuai dengan pengamatan

Ha : Model yang terbentuk tidak sesuai dengan pengamatan

Dasar pengambilan keputusan:

Jika nilai sig. Hosmer and Lemeshow Test $>$ 0,05 maka Ho diterima

Jika nilai sig. Hosmer and Lemeshow Test $<0,05$ maka $\mathrm{H}$ diterima Analisis:

Dari hasil perhitungan SPSS 26. Dapat terlihat bahwa nilai sig. Hosmer and Lemeshow Test $>0,05$ yaitu $(0,06>0,05)$ maka Ho diterima. Hal ini diartikan bahwa model yang pakai sesuai dengan pengamatan, maka uji regresi logistik dilanjutkan.

4. Menguji signifikan parameter (uji parsial)

Negelkerke R Square pada Tabel 3 menunjukkan nilai sebesar 0,255 atau 25,5\%. Hal ini berarti, variabel dependen dapat dijelaskan oleh variabel-variabel independen sebesar 25,5\%. Artinya, seluruh variabel independen mempengaruhi 
variabel dependen pada kisaran 25,5\% sedangkan 74,5\% lainnya dipengaruhi atau dijelaskan oleh variabel-variabel yang tidak dimasukkan dalam penelitian ini. Untuk memprediksi dengan benar dapat dilihat dengan nilai classification Tabel.

Tabel 3. Hasil uji estimasi parameter model

\begin{tabular}{|c|c|c|c|}
\hline \multicolumn{4}{|c|}{ Model Summary } \\
\hline & $-2 \log$ & Cox \& Snell R & Nagelkerke R \\
\hline Step & likelihood & Square & Square \\
\hline 1 & $174.943^{\mathrm{a}}$ & 0,181 & 0,255 \\
\hline \multicolumn{4}{|c|}{$\begin{array}{l}\text { a. Estimation terminated at iteration number } 5 \text { because } \\
\text { parameter estimates changed by less than } .001 \text {. }\end{array}$} \\
\hline
\end{tabular}

5. Estimasi model regresi. 3.

Dari Tabel 4 didapatkan penjelasan bahwa hasil Pemeriksaan Miopia pada siswa Sekolah Dasar yang diadakan pada program pengabdian Masyarakat di Daerah JABODETABEK sebanyak 305 siswa dengan sampel 169 siswa, hasil pemeriksaan siswa yang ada miopia rendah 96 siswa dan yang miopia sedang sebanyak 25 siswa. Ketepatan dalam memprediksi 72,8\%.

Tabel 4. Classification

\section{Classification Table}

Observed

\begin{tabular}{llllll}
\hline Step 1 & myopia & rendah & 96 & 21 & 82,1 \\
& & sedang & 25 & 27 & 51,9 \\
\hline Overall & & & & 72,8 \\
& Percentage & & & & \\
\hline
\end{tabular}

a. The cut value is .500

\section{KESIMPULAN}

Di era pandemi Covid-19 saat ini peran smartphone menjadi penunjang satusatunya sarana dalam pembelajaran daring, selain laptop. Intensitas penggunaan smartphone atau handphone mempengaruhi terhadap kelainan refraksi pada khususnya miopia, hal dibuktikan dengan uji regresi logistik dengan SPSS 26 yaitu 0,000<0,05 
dengan besarnya pengaruhnya yaitu $25,5 \%$ dari intensitas penggunaan handphone dan $74,5 \%$ dipengaruhi oleh variabel lain. Penggunaan uji regresi logistik untuk penelitian ini sudah tepat, hal ini dibuktikan dengan Hosmer and Lemeshow Test $>0,05$ yaitu ( 0,06 > 0,05) maka Ho diterima. Hal ini diartikan bahwa model yang pakai sesuai dengan pengamatan. Begitu pun dengan ketepatan dalam memprediksi pengujian ini sebesar $72,8 \%$.

\section{UCAPAN TERIMA KASIH}

Ucapan terima kasih kepada segenap mahasiswa Angkatan 12, Dosen Pendamping dan semua pihak yang terlibat Akademi Refraksi Optisi Kartika Indera Persada, akan terlaksananya program pengabdian masyarakat di tengah pandemi Covid-19 hingga penelitian ini bisa diadakan.

\section{DAFTAR PUSTAKA}

Azizah, S. M., \& Chandra, N. E. (2017). Model Regresi Logistik Pada Faktor-Faktor Yang Mempengaruhi Imunisasi Lengkap Balita. Jurnal Ilmiah Teknosains, 3(2), 3-6. https://doi.org/10.26877/jitek.v3i2.1882

Bremond-Gignac, D. (2020). Myopia in children. Medecine Sciences: M/S, 36(8-9), 763768.

Falaki, H., Mahajan, R., Kandula, S., Lymberopoulos, D., Govindan, R., \& Estrin, D. (2010). Diversity in smartphone usage. Proceedings of the 8th International Conference on Mobile Systems, Applications, and Services, 179-194.

Haryanti, S. (2021). Statistika Dasar Untuk Penelitian Jilid 1 Dengan Aplikasi SPSS: Pada bidang Pendidikan, Sosial dan Kesehatan. Media Sains Indonesia.

Hosmer, \& lemeshow and. (2007). Applied Logistic Regression. In Journal of Environmental Health (Vol. 70, Issue 3).

Lapau, B. (2014). Metode Penelitian Kesehatan; Metode Ilmiah Penulisan Skripsi, Tesis, dan Disertasi.

McCrann, S., Loughman, J., Butler, J. S., Paudel, N., \& Flitcroft, D. I. (2021). Smartphone use as a possible risk factor for myopia. Clinical and Experimental Optometry, 104(1), $35-41$.

Sativa, O. (2010). Tekanan Intraokular Pada Penderita Myopia Ringan Dan Sedang. Bagian Ilmu Penyakit Mata Universitas Sumatera Utara. Diakses Dari e-Medicine.

Wolffsohn, J. S., Flitcroft, D. I., Gifford, K. L., Jong, M., Jones, L., Klaver, C. C. W., Logan, N. S., Naidoo, K., Resnikoff, S., \& Sankaridurg, P. (2019). IMI-myopia control reports overview and introduction. Investigative Ophthalmology \& Visual Science, 60(3), M1-M19. 


\section{(c) (i)}

(C) 2021 by authors. Content on this article is licensed under a Creative Commons Attribution 4.0 International license. (http://creativecommons.org/licenses/by/4.0/). 